\title{
New Composition Concept for Keroncong Music in the Oboe Concerto with Keroncong and Orchestra
}

\author{
Singgih Sanjaya \\ Music Department, Indonesia Institute of the Art Yogyakarta \\ Parangtritis street km. 6,5 - Yogyakarta, Indonesia
}

\begin{abstract}
This research aims to design a new concept in keroncong music creation with an explorative method. Keroncong is one kind of entertainment musics in Indonesia that has a long existece and evolved up to today. Keroncong music is a musical mixture of a Western diatonic music with Javanese gamelan music. The term of keroncong comes from the sound "...crong crong crong..." on the ukulele instrument that played rasquardo. An instrumentation music consists of: vocals, violin, flute, cak, cuk, cello, guitar, and bass. During this moment, keroncong is basically just served as a vocal accompaniment music. This becomes a driving force for the author to compose a special composition for keroncong music solo instrument. There is a new concept used in the arranging of this composition, as follows. This composition is designing a concerto, which is a type of the instrumental musics with a Western diatonic instrument on the part-one of the solo oboe and an English horn in part-two, with keroncong music and orchestra. The conclusion of these designs are as follows. Keroncong music will be able to stand on its own as an instrumental music.
\end{abstract}

Keywords: new concept of composition, keroncong, oboe, orchestra

\section{INTRODUCTION}

A few months after the author took a private flute learning, the author becomes very interested in keroncong music which becomes a part of the culture in his hometown, Surakarta. After several months learning the flute, the author is invited to join a keroncong music group led by Waljinah as a flute- two, in the mid of 1977. From the author's experience as a keroncong flute player up to 2005, none of keroncong music creation is specifically created for an instrumental music. During the time, keroncong is basically just served as a vocal accompaniment music. This prompted the author to compose a special composition for keroncong music solo instrument. The author has been challenged because he studied the classic music formally at Musical Middle High School Yogyakarta, and continued to the Department of Music ISI Yogyakarta. 
This research designs a new concept in keroncong music creation using an explorative method. Some new concepts are designed in the arranging of this composition, as follows. This composition is designing a concerto, which is one type of instrumental Western diatonic music compositions with an oboe solo instrument on the part-one and an english horn in part-two, with keroncong music and orchestra. The oboe and the english horn instrument became the primary instruments in this kind of composition. This composition explores the instrument's playing techniques.

Keroncong music which is basically just played as an entertainment music which is obviously as an 'easy listening' music, uses the tonal scales. The arranging of this composition also uses the atonal scales on part-two as a new thing in keroncong music. The rhythm patterns that oftenly used in keroncong music are: single, dobel (double), kothek'an, kentrung, and sambyong. The author explores the rhythm pattern of Kothek'an by using only one tone. The rhythm section instruments which are usually only play the rhythm in improvisation based on chord, in this design plays in unisono atonal melodies. Harmony in music keroncong is relatively simple. This design is used in a much more varied harmony, which also uses jazz harmony. Similarly, the measures of usage. Keroncong songs (original keroncong, langgam keroncong style, and stambul) only use the measures of $4 / 4$. The creation of this composition which is using several measures other than $4 / 4$ is to get the feel/nuance that is apart from the steadiness feeling or 'monotonous'.

\section{ORIGINS OF KERONCONG MUSIC IN INDONESIA}

Discussing about the history and keroncong music development rom the 17th-century, precisely in 1661 when the Portuguese began to inhabit the Kampung Tugu in Batavia up to today-will never be separated from the history of the archipelago itself. The Portuguese has advanced navigation technology which have contributed to the formation of Indonesian culture. In addition to dissemination of religion, politics, economics, the Portuguese influence the art of Indonesia, one of them is music.

Keroncong is the oldest popular music than others, which survived until the 21st century today, and the hallmark of the authentic owned by Indonesia at this time. In the view of Ganap (2008: 24), keroncong only in Indonesia. Accordingly, the Portuguese simply left the instrument (cuk-cak). Then, those has been modified in such a way by the Indonesian nation. While the songs that we know today, with many forms, is not separated from the role Kusbini, who was in the 70s, created a sense of Indonesia keroncong, which in Portugal (Portuguese now), that never existed. Likewise in other countries.

Keroncong from the original time (17th century), is a unique music. Not to mention the time when keroncong music arrived to Java, at the beginning of the 20th century, it has a connection (syncretism) which is quite strong with Javanese gamelan. Moreover, other forms are subsequently emerged such as Langgam 
Keroncong, Stambul, Original Keroncong, and so forth.

Aftr the 1980s, or in the decade of the 1990s precisely, there were many changes in keroncong music. There are several musical expansions, such as the inclusion of gamelan instruments directly, thus forming the birth of campur sari, pioneered by Manthous. There is also congdut (mixture between keroncong and dangdut). The general instrumentations used are ukulele (representing keroncong), and ketipung (representing dangdut), also combined with modern music instruments), which combines keroncong with dangdut. Similarly, there congrock, (mixture between keroncong music and rock). Marco Marnadi can be said as the pioneer of modern congrock, with the instruments expand, generally used such as band instruments in keroncong which combines keroncong with Rock, which Marco Marnadi of Semarang, and other movements that are also considered successful in bringing the young generation creative keroncong and became a significant reformer.

This could be noticed more for the common statement that always states, Keroncong music is the music for the elder generation. While in fact, for example in Kampung Tugu nowadays also known as a Tugu community of keroncong which actually played by the children. This can be used as an evident that the life of the this community has survived more than 13 generations there, which all players are children. In some cities, such as Solo, Yogyakarta, Semarang, Jakarta, Surabaya, the younger keroncong musicians occupy an important role, because they always create innovations, which makes keroncong able to survive with new repertoires, new music composition, as well as the expansion of the listeners segment.

According Ganap (2011: 98), in a musicological perspective, keroncong history can be traced from the traditional music and Portuguese song-dance played in the 17th century. For example Fado de Coimbra, a traditional music of Coimbra, the largest city after Lisbon, capital of Portugal. There is also Camelias, a folk dance. Besides those, obviously the song of Moresco and Kr. (Keroncong) Moresco, as a strong evidence of the Moorish art history. The song of Kr. Moresco is famous among musicians keroncong today, and popular as a form of original keroncong. Kusbini is the maestro who introduced Moresco song to the audience at the firsttime. The conclusions stated by Ganap, the Indonesian keroncong music has the elements of Portuguese music of the 16th century that were influenced by the Islamic culture of the Moors from North Africa who were entering and growing in Portugal. It can be seen, that keroncong stays alive and become an authentic cultural richness, both in terms of musical as well as the values of its humanity.

\section{INSTRUMENTAL KERONCONG MUSIC}

Reading from the existing advancement, generally keroncong is a music for vocal accompaniment. As far as the data that owned by the author, there is no keroncong as a result of an instrumental work, it means that it stands as a 
pure music without any vocals. Thus the authors feel challenged to innovate an instrumental keroncong music composing.

So far the author compiles some reasons. First, the scarcity of keroncong instrumental music. Second, creating a new aesthetic on keroncong music. Third, to bring keroncong music into the realm of the more "serious", in an appreciative understanding. Fourth, this option has become the mission of the author who could be mentioned who have engaged long enough in keroncong music, as a player or an arranger.

The instrumental keroncong music scarcity can be seen from the scarcity of keroncong music recordings on the market. In fact, according to the authors, none of the keroncong music is created for an instrumental. Keroncong "Jali-jali", which became one of keroncong icons, the original is not an instrumental, a song that originated from Betawi kromong xylophone, which is also uses poetry/lyrics on its song. While the aesthetics of the composition to be achieved is related to the expansion of the structure and techniques in keroncong music, orchestra, and solo instruments that play it. There is a different challenge when composing a non-keroncong instrumental music with a keroncong instrumental music. The particular challenge is on how to transform the idiom and keroncong medium into an orchestral music, as well as how to address the technical ability of an instrument as a solist.

During this time, keroncong is also known simply as an entertainment music. This time the author would like to bring it to the "serious music", in the sense of an appreciative understanding viewed from the side of composing it. The results of this work can still be enjoyed by all audiences. An appreciative music is a music that is able to invite a deeper question about the creative process of the music itself. As for the creativity element in the instrumental keroncong music creation lies in the preparation of the new musical elements by not leaving the taste of keroncong music which is already well established, for example in the case of knitted rhythmic and harmony. This effort will make people have a more careful choice of keroncong music that had been circulating in the market.It is also a shape of the author's accountability as an artist who also was born at an academic sphere. Besides, the author has a long enough track record with keroncong music as artist, author also experiences an academic music education, these combination will be a great challenge for the author.

\section{ART MUSIC - KERONCONG}

According to Adorno (2011: 76), there are some significant differences between an entertainment music and a serious music, or Adorno called it by the term of "serious music" and "light music". The difference is mainly on the aspects of the process. An entertainment music merely for the commercial purposes, while the serious music (art music) is for the appreciation purposes, although they both were in the popular music area. Adorno gave the example that the flood of the pop music and hits, the critical power of the listening has decreased. They are 
getting more accustomed to vulgar lyrics and the all mechanical and passive formulation. The listener is no longer childlike (inquisitive and critical), but he/she becomes childish with low power appreciation.

Adorno (2011: 53) also emphasizes on the sociopsychological function in music, concerning on how a closer connection between the audience and the music itself. By doing so, according to Adorno, that would create an appreciation. Similarly, in an instrumental keroncong music. The level of success of the appreciation of this composition is that when people have the response then an intensive dialectic occurs.

This kind of effort is demanding a musical life after the stage. The appreciation thereafter should be done continously to achieve the target of a real music appreciation. Hence, in addition to this work as a result of a creative manner, this study is also necessary which is likely to expand the horizon of the people to music, besides as a spectacle, as well as a guide for people to understand the many values in music that have not come to the surface yet.

\section{ORIGINAL KERONCONG SONG SPECIFICATIONS, LANGGAM KERONCONG, STAMBUL}

Keroncong has a uniqueness on its song type that is basically has three types of songs, namely: original keroncong, langgam keroncong style, and stambul. The three form of those songs are distinguished by the wording, chord progressions, the number of bars, introduction and its interlude. Besides those three form of the songs, according to Harmunah is classified as 'extra tracks'.

Original Keroncong, has several distinctive characteristics, namely: the number of its bars: 24 bars, measures of 4/4, started with voorspel, song form A - B - C, diatonic scales, with chord progressions as follows:

$$
\begin{aligned}
& \text { I . . IV . V . I . . I . . V . . V . . I . V . . (sentence A) } \\
& \text { I ...IV . V . I . I . . V . V . I . . I . . (sentence A') } \\
& \text { IV . . IV . V . I . . I . . II . . II . . V . . V . . (sentence B, reffrain) } \\
& \text { I . . IV . V . I . I . . V . . V . I . . I . . (sentence A') }
\end{aligned}
$$

This original keroncong style was preceded by the introduction called voorspel, a cadenza series that consisting of three phrases. A cadenza is usually played by a flute, a violin, or a guitar. Cadenza on the first phrase ends on the chord-I followed by 'rhythm section'.

Cadenza on the second phrase ends on the $\mathrm{V}$ chord which is also followed by the rhythm section. The third Cadensa or last ended on the chord-I followed by a rhythm section that directly play a rhythm pattern (usually engkel rhythm). Then, the violin or flute play the melody referred to as 'senggaan' (a melody that consists of four bars, taken from the last eight bars, including the hung bars). This original keroncong type is usually sung twice. After the singer sings the whole song, music plays an interlude in the form of 'senggaan' as the previous. Song example: Kr. (Keroncong) Moritsko, Kr. Tanah Airku, Kr. Bandar Jakarta. 


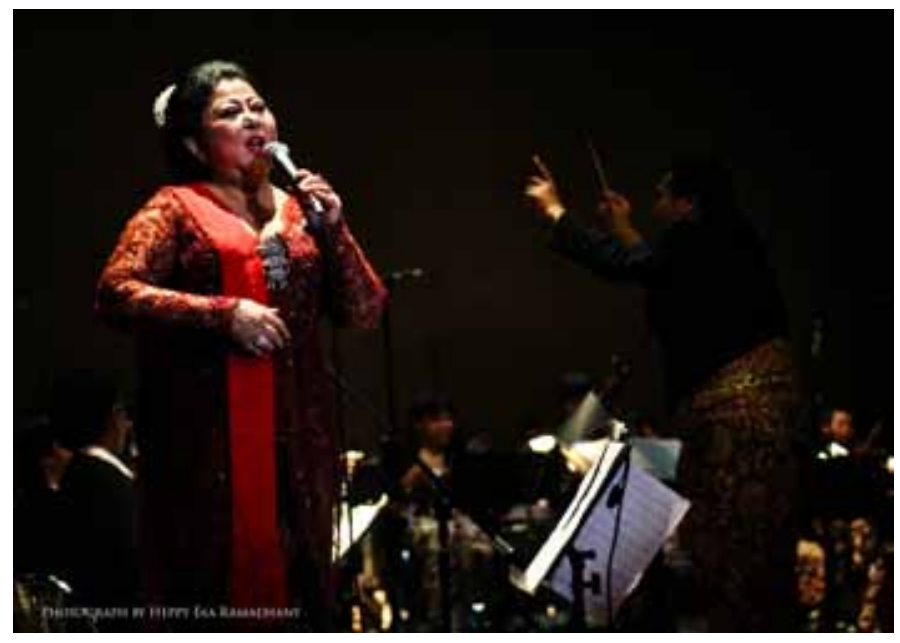

Figure 1: Waljinah sings Keroncong Moritsko

in Light Keroncong Orchestra Concert Music Director, Conductor, Composer, Arranger: Author at Taman Budaya Concert Hall Yogyakarta, Juli 2008 (photo: Author's collection)

Langgam Keroncong has the characteristics as follows: the bars number: 32 bars, measures of $4 / 4$, the form of the song A - A '- B - A', in the pop music form is called 'song form', with diatonic scales, some chord progressions, as the following:

$$
\begin{aligned}
& \text { I ...IV . V . I . I . . V . . . . I . . . . (sentence A) } \\
& \text { I . . IV . V . I . . I . . V . . V . . I . . I . . . (sentence A') } \\
& \text { IV . . IV . V . I . . I . . II . . II . . V . . V . . (sentence B, reffrain) } \\
& \text { I . . IV . V . I . . I . . V . . V . . I . . I . . (sentence A') }
\end{aligned}
$$

The style of 'Langgam Keroncong' is usually preceded by the introduction of the melody which is usually played by a flute or a violin, and took this last 4 bars of its song melody (along with the hung bars). Langgam Keroncong style usually played one and a half songs. After the introduction, vocal sings a full song, and then continued to the interlude part (melody played by a violin or flute) that plays the phrase $\mathrm{A}^{\prime}$, then continued with the singing vocal of phrase $\mathrm{B}$ (reffrain) followed by sentence/phrase A'. Song example: Lg. (langgam) Bengawan Solo, Lg. Rangkaian Melati.

Langgam keroncong style (song form) was first used by Gesang in Langgam song Bengawan Solo that became one of the legendary and popular songs up in foreign countries.

Stambul has characteristics as follows: the number of bars: 16 , measures of $4 / 4$, the form of the song A - B, diatonic scales, with chord progressions as follows:

$$
\begin{aligned}
& \text { I . . I . . IV . . IV . . IV . . IV . V . I . . IV . V . . (sentence A) } \\
& \mathrm{I} \ldots \mathrm{I} \ldots \mathrm{V} \ldots \mathrm{V} \ldots \mathrm{V} \ldots \mathrm{V} \ldots \mathrm{I} \ldots \mathrm{V} \ldots \mathrm{\text {(sentenceB) }}
\end{aligned}
$$


This type of stambul song also has a unique characteristic. The stambul song Introductions is usually played by a guitar instrument that plays a chord phrase I, improvised with broken chord technique approach (playing the tones regularly or randomly, based on the chord tones). After the guitar introduction, the first vocal is sung recitatively (a Western diatonic term which the meaning of the uncountable way of singing, same as people talking) without accompaniment on the early two bars of the song, which is forwarded to the accompaniment to the fully one song.

After singing a fully song (16 bars) vocal sings a full song (the same melody) with the second lyrics (without recitative as in the beginning part). After the interlude played by violin and flute, for example, the violin plays the sentence-A and continued to the violin that plays the sentence-B, or vice versa. After the interlude of one fully song has been completed, followed by the vocal which plays a full song (without recitative as in the beginning part). Singing and playing on these types of stambul songs demand more 'patient', because it has a relatively slower tempo and usually use engkel rhythm (rhythm pattern) only. Kusbini, one of the Indonesia keroncong maestro, did not allow using the double rhythm pattern in a stambul song. Song example: Stb. (stambul) Baju Biru, Stb.Kecewa, Stb. Jauh Di Mata.

\section{THE CONCEPT OF OBOE CONCERTO CREATION WITH KERONCONG AND ORCHESTRA}

From the author's experience since 1977 as a keroncong flute player up to the year of 2005, none of the keroncong music creation was specifically created for an instrumental music. During this time keroncong music is basically served as an entertainment music, as vocal accompaniment. This becomes a driving force for the author to compose a special composition for solo instruments for keroncong music. So far, the author has been noticing that, there is no concerto work for keroncong music. The musical concept designed on the concerto creation is: instrumentation, scales, harmony, and measures.

Keroncong music instrumentation generally consist of: vocals, flute, violin, cak, cuk, cello, guitar, and bass. This work formed in concerto with the instrument composition as follows: Oboe is a solo instrument or the main instrument on the part-one and the English horn as a solo instrument in the second part with keroncong music and orchestral accompaniment. Keroncong consists of: cak, cuk, cello, guitar, and bass. The orchestra consists of: 2 flutes, oboe, French horn, trumpet, trombone, chimes, xylophone, violin 1, violin 2, viola, violoncello, and contrabass.

Scales used in keroncong music is diatonic scales, that are the major and minor scales. In addition, this work is using a major-minor scale, on part-two also uses atonal music, as the following : 


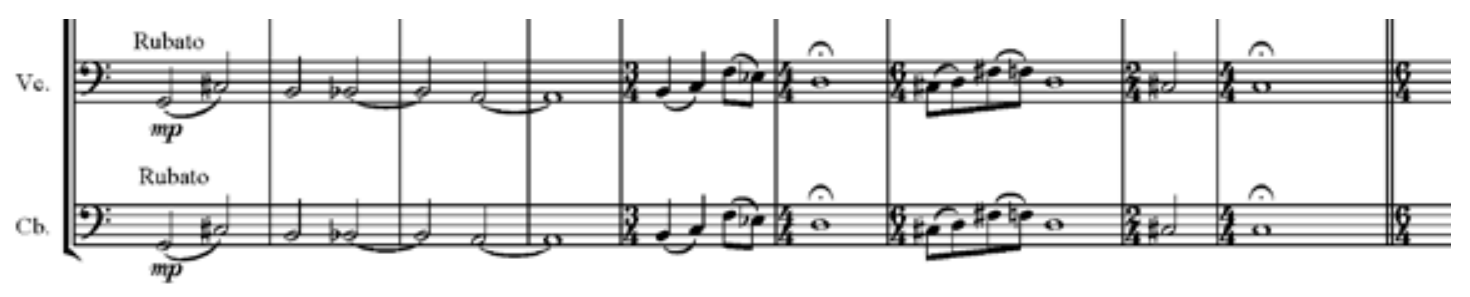

Notation 1: violoncello and contrabass bars of $12-20$, using atonal scales

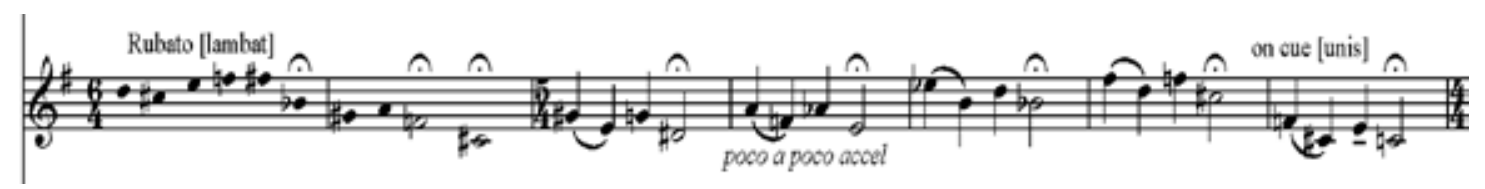

Notation 2: English horn bars of $21-27$, using atonal scales

There are few keroncong rhythmic patterns in, namely: engkel, dobel, kothek'an, kentrung, and sambyong. The new conept of the accompaniment pattern in this composition is, kothek'an rhythm pattern which uses one tone only. Typically, kothek'an accompaniment patterns using the tones in the chords [broken chord].

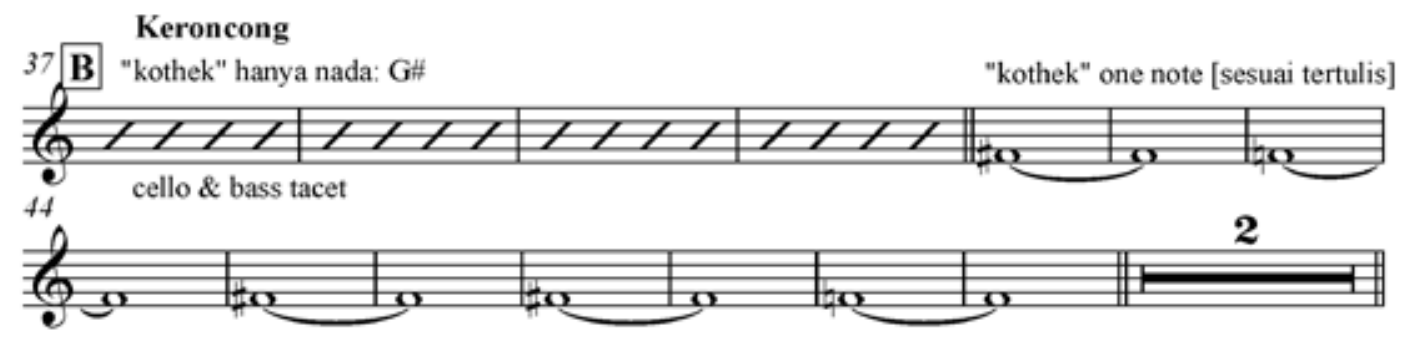

Notation 3: 37-50 bars rhythm section, the rhythm pattern kothek'an one tone

Keroncong rhythm section consisting of cak, cuk, cello, guitar and bass which plays a melodic phrase in unisono using atonal scales is also a new concept that is used in the arranging of this composition.

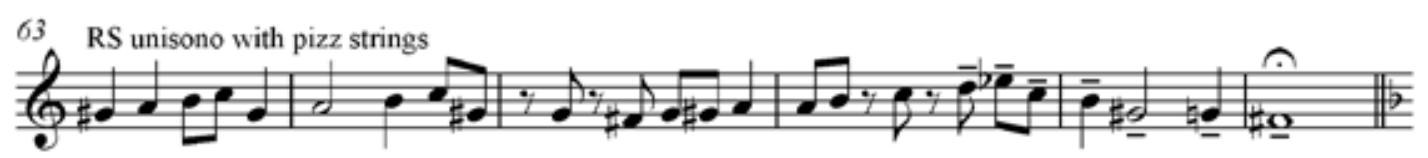

Notation 4: bars of 63-68 rhythm section, fiddling the melody, unisono with pizzicatto strings.

The harmony in Keroncong music is simple, whether is in the chord progressions or in the kind of its chord. The chord progressions of Keroncong music that have been written is a simple chord, which is functioned as a progression "pattern" for each track. Mostly of the original keroncong songs and stambul basically use progressions as above. It could not be applied on langgam keroncong style. There are at least six progression patterns used in langgam keroncong types. The type of chords on keroncong music is also simple. Basically, the types of chords used are: major, minor, and dominant septime are sometimes added with diminished and augmented chord types. 
Harmony concept used in this oboe concerto is not a pattern and the chord type used unlimitedly as well. As an example of progressions and the chord type of the early part of the bars for a string/friction section.

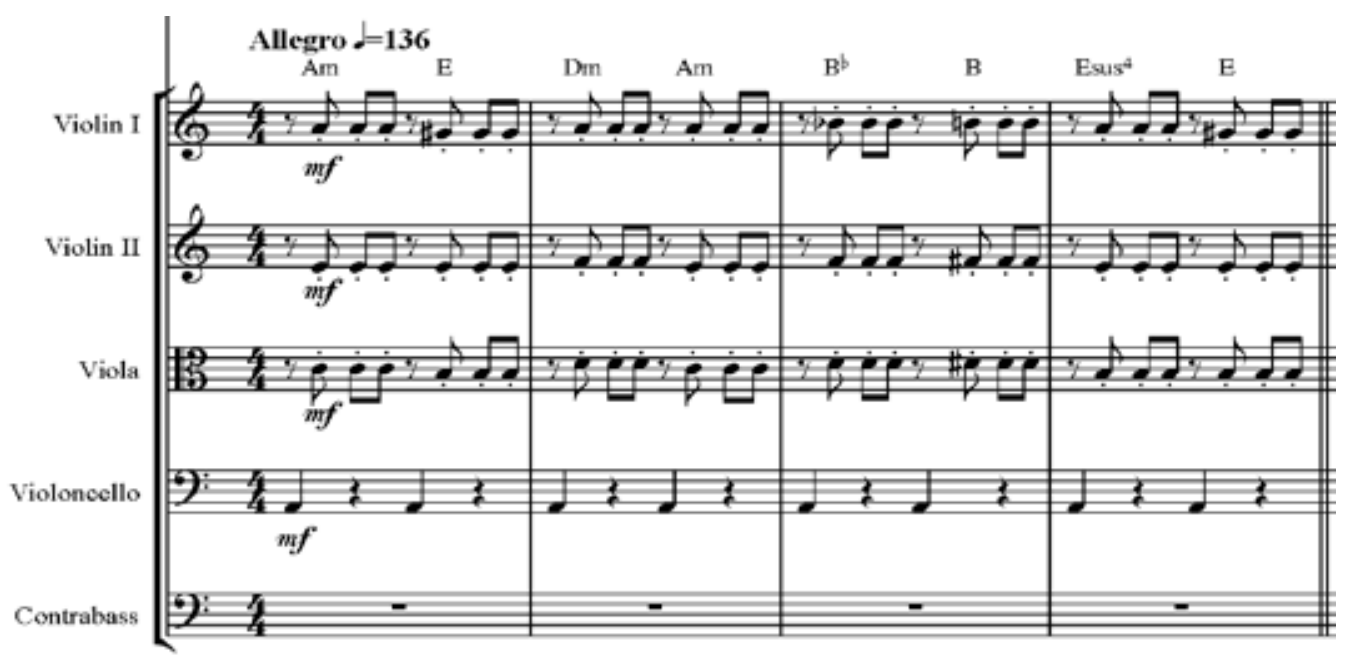

Notation 5: string section bars of 1-4, using progressions and different types of chord

The measures of $4 / 4$ is the only one used in all keroncong songs. The arranging concept of this oboe concerto uses unrestricted measures. In part 1 of this work usies the measures of 4/4. Part 2 of this composition uses unlimited measures.
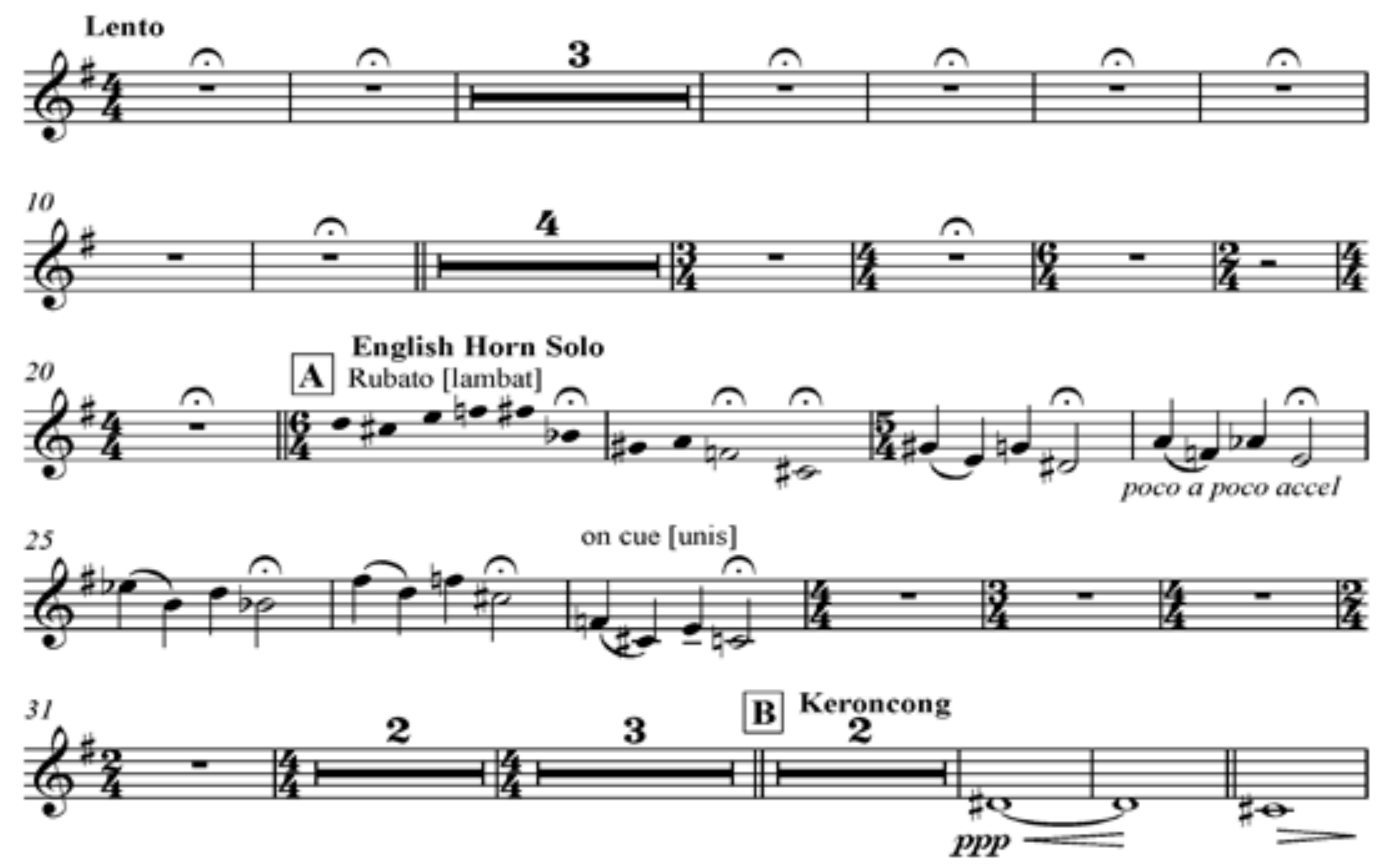

Notation 6: English horn bars of 1-41, the use of measures of part 2

Part 2 of this composition uses several measures, which basically aims to eliminate the impression of 'patterned' measures. Bars 1-15 use the measures of 4/4, bars of 16 uses the measures of $3 / 4$, bars of 17 uses the measures of $4 / 4$, bars of 18 uses the 
measures of $6 / 4$, bars of 19 uses the measures of $2 / 4$, bars of 20 uses the measures of 4/4, Bars of 20-21 use the measures of $6 / 4$, bars of 23 using the measures of $5 / 4$, bars of 20-27 use the measures of $4 / 4$, and so on.

\section{DESIGN RESULT}

The Results of this new concept of keroncong music composition design creation is a musical composition entitled Oboe Concerto with Keroncong and Orchestra, which consists of two parts. Allegro Spirituoso as the Part One. Lento as the Part Two. These compositions have been performed in Solo International Keroncong Festival, in Ngarsopuro Solo, in 2012, by Keroncong Light Orchestra, founded and led by the author. This composition is an adaptation and advancement of a composition titled Clarinet Concerto with Keroncong and Orchestra, which has been performed at Taman Budaya Yogyakarta, in 2009.

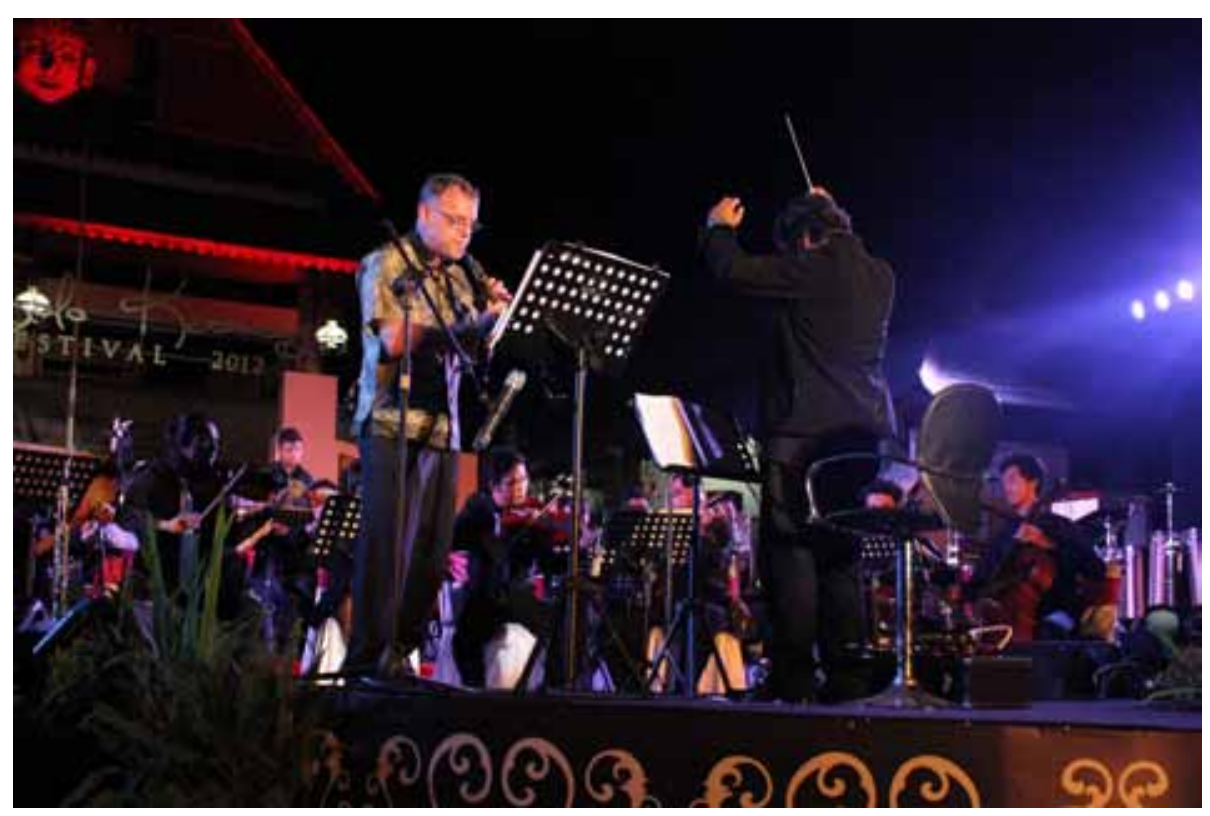

Figure 1: Joost C Flach played solo oboe of Oboe Concerto with Keroncong and Orchestra in the Solo International Keroncong Festival Light Keroncong Orchestra

Music Director, Conductor, Composer, Arranger: Author at Taman Budaya Seminar Room Yogyakarta, September 2012 (photo: Author's collection)

The Composition can be watched/downloaded on YouTube in two versions. First Version, live version :

Singgih Sanjaya Concerto Oboe part 1 [https://youtu.be/0OGq0GTAjro] and Singgih Sanjaya Concerto Oboe part 2 [https://youtu.be/1HOHL2iB_BI]

Second Version, recorded version:

Singgih Sanjaya Oboe Concerto 1st LKO 2012 [https://youtu.be/3UldqAxTMz0] Singgih Sanjaya Oboe Concerto $2^{\text {nd }}$ [https://youtu.be/1HOHL2iB_BI]

Singgih Sanjaya Clarinet Concerto $1^{\text {st }}$ LKO 2008 [https://youtu.be/ZYZRXO-7VVc] Singgih Sanjaya Clarinet Concerto $2^{\text {nd }}$ LKO 2008 [https://youtu.be/kwCnVf2ed8w] 


\section{RESULT}

Several conclusions from this scheme are as follows: Keroncong music which initially served as a vocal musical accompaniment, will be able to stand alone as an instrumental music based on this design. Keroncong music not just only served as a musical entertainment, but this can be classifed as an 'art music', since it is complexly composed from the composer side. Although the composition of the Oboe Concerto is an adaptation and advancement of Clarinet Concerto with Keroncong and Orchestra, the exploration of this composition arranging still needs to be developed.

\section{REFERENCES}

Budiarto, C. Teguh. 2001. Musik Modern dan Ideologi Pasar. Tarawang Press.

Budiman, Hikmat. 2002. Lubang Hitam Kebudayaan. Yogyakarta: Kanisius.

Ganap, Victor. 2011. Krontjong Toegoe. BP ISI Yogyakarta.

Ganap, Victor "Musik Keroncong Hanya Ada di Indonesia", Gong, Edisi 105/IX/2008.

Harmunah. 1996. Sejarah, Perkembangan, dan Gaya Musik Keroncong. Yogyakarta: Pusat Musik Liturgi.

Kennedy, Michael dan Kennedy, Joyce. 2007. Oxford Concise Dictionary of Music. New York: Oxford University Press Inc.

Korsakof, Nikolay Ramsky. 1964. Principles of Orchestration. New York: Dover Publication Inc.

Sriwidjadjadi, R. Agoes. 2007. Mendayung di Antara Tradisi dan Modernitas Sebuah Penjelajahan Ekspresi Budaya Terhadap Musik Keroncong. Yogyakarta: Hanggar Kreator.

Purba, Mauly dan Ben Pasaribu. 2006. Musik Populer. Jakarta: Lembaga Pendidikan Seni Nusantara (LPSN).

\section{Papers}

Alfian, Magdalia. 2006. Seni Pertunjukan dalam Perspektif Sejarah: Keberadaan Musik Keroncong di Indonesia. Seminar Sejarah, Balai Kajian Sejarah dan Nilai Tradisional. 